\title{
Matrix metalloproteinase-2, tissue inhibitor of matrix metalloproteinase-2, and transforming growth factor beta $I$ in the aqueous humor and serum of patients with pseudoexfoliation syndrome
}

This article was published in the following Dove Press journal:

Clinical Ophthalmology

29 January 2014

Number of times this article has been viewed

\author{
Selcuk Kara' \\ Nilgun Yildirim ${ }^{2}$ \\ Ahmet Ozer ${ }^{2}$ \\ Omer Colak ${ }^{3}$ \\ Afsun Sahin ${ }^{2}$ \\ 'Department of Ophthalmology, \\ Canakkale Onsekiz Mart University \\ School of Medicine, Canakkale, \\ ${ }^{2}$ Department of Ophthalmology, \\ Eskisehir Osmangazi University \\ Hospitals, Meselik, Eskisehir, \\ ${ }^{3}$ Department of Biochemistry, \\ Eskisehir Osmangazi University \\ Hospitals, Meselik, Eskisehir, Turkey
}

Purpose: The aim of the study reported in this article was to determine the presence and quantitative differences of matrix metalloproteinase-2 (MMP-2), its tissue inhibitor (TIMP-2) and transforming growth factor beta 1 (TGF- $\beta 1$ ) in the aqueous humor and serum samples of patients with pseudoexfoliation (PEX) syndrome.

Methods: Aqueous humor and serum samples were collected from 32 patients with PEX syndrome (with and without glaucoma) and a control group, who underwent routine cataract surgery. Levels of MMP-2, TIMP-2, and TGF- $\beta 1$ were determined by specific immunoassays (enzyme-linked immunosorbent assay).

Results: MMP-2, TIMP-2, and TGF- $\beta 1$ were identified in aqueous humor and serum samples from all groups of patients. The aqueous and serum samples of MMP-2, TIMP-2, and TGF- $\beta 1$ showed no significant differences between PEX syndrome and control groups. Serum levels of MMP-2, TIMP-2, and TGF- $\beta 1$ were statistically greater than their aqueous levels $(P<0.05)$, except for TIMP-2 levels in the control group.

Conclusion: No statistically significant difference among mean MMP-2, TIMP-2, and TGF- $\beta 1$ levels in both aqueous humor and serum samples was found between patients with PEX syndrome and the control group. It is important to simultaneously evaluate serum and aqueous samples from patients with PEX syndrome, which is related to an impaired blood-aqueous barrier.

Keywords: MMP-2, TIMP-2, TGF- $\beta 1$, PEX glaucoma, PEX syndrome

\section{Introduction}

Pseudoexfoliation (PEX) syndrome is a systemic disease characterized by excessive synthesis and progressive accumulation of a fibrillar material in various tissues, including the eye. ${ }^{1}$ The composition of these fibrils includes basement membrane components. It is thought that elevated transforming growth factor beta 1 (TGF- $\beta 1$ ) and oxidative stress disrupt the expected balance between matrix metalloproteinases (MMPs) and their tissue inhibitors (tissue inhibitors of matrix metalloproteinases [TIMPs]). This imbalance leads to accumulation of exfoliative material as well as extracellular matrix (ECM) deposition, which is the most common cause of PEX glaucoma. ${ }^{2-4}$

MMPs are regulated at the levels of transcription, secretion, and the proteolytic activation of their precursors. ${ }^{5,6}$ It has been shown that MMPs are locally synthesized
Correspondence: Nilgun Yildirim Department of Ophthalmology, Eskisehir Osmangazi University Hospitals, Meselik, 26480, Eskisehir, Turkey

Tel +90222 229 I00I

$\mathrm{Fax}+902222390928$

Email nyyildirim@yahoo.com 
by trabecular cells, especially in PEX syndrome and glaucoma. ${ }^{7}$ MMPs and TIMPs are usually regulated by cytokines such as TGF- $\beta 1$ and transforming growth factor beta $2 .{ }^{4,8}$ Elevated TGF- $\beta 1$, which is synthesized by the ciliary body epithelium, induces the secretion of matrix metalloproteinase-2 (MMP-2) and tissue inhibitor of matrix metalloproteinase-2 (TIMP-2). However, the activated form of MMP-2 was significantly decreased in patients with PEX syndrome and glaucoma. ${ }^{3,4}$ Although there should be a balance between MMPs and TIMPs, this is disrupted in PEX cases, resulting in an excess of TIMP- 2 over MMP-2. ${ }^{3}$ This may lead to the accumulation of ECM in the trabecular meshwork (TM). However, there is remarkable variability in results of recent studies on PEX syndrome that measured the aqueous levels of these enzymes and cytokines., ${ }^{3,9-12}$ This variability may be related to extravasation in connection with PEX syndrome, treatment of PEX glaucoma with topical prostaglandin analogs, and inflammation and/or oxidative stress of any other ocular or adjacent tissue.,.$^{3,12-15}$ This striking finding may support the active production of MMPs and TIMPs by anterior-segment ocular tissues. To date, there are limited data simultaneously comparing the serum and aqueous levels of ECM turnover actors (MMP-2, TIMP-2) and their key regulator, TGF- $\beta 1$. Thus, in the study reported here, we investigated whether any association was present between the aqueous and the serum concentrations of MMP-2, TIMP-2, and TGF- $\beta 1$, simultaneously in eyes with cataract, PEX syndrome, and PEX glaucoma.

\section{Subjects and methods Subjects and samples}

Informed consent was obtained from the patients prior to the study, and the tenets of the Declaration of Helsinki for experiments involving human tissue were followed.

Aqueous humor was aspirated during surgery from 22 patients with PEX syndrome with $(\mathrm{n}=10)$ and without $(\mathrm{n}=12)$ glaucoma (mean age \pm standard deviation $73.9 \pm 4.8$ years) and from ten control patients with cataract (mean age \pm standard deviation $66.3 \pm 13.8$ years). Aqueous humor was withdrawn through a limbal paracentesis site with a 27 -gauge needle on a tuberculin syringe. Meticulous care was taken to prevent contamination of the aqueous samples with blood. The samples were immediately frozen in liquid nitrogen and stored at $-80^{\circ} \mathrm{C}$. Samples of serum were also collected from patients of each group and stored in the same way.

Patients with other ocular or systemic diseases, such as inflammatory diseases or diabetes mellitus, or a history of previous ocular surgery, were excluded from the study.

\section{Enzyme immunoassays of MMPs, TIMPs, and TGF- $\beta$ I}

The total (pro, active, and complexed forms) concentrations of MMP-2 (gelatinase A) and TIMP-2 were assessed in aqueous humor and serum with commercially available sandwich enzyme immunoassay kits (Calbiochem ${ }^{\circledR}$; EMD Biosciences, Darmstadt, Germany). Assays were performed according to the manufacturer's instructions. The sensitivity of the assays used was $0.5 \mathrm{ng} / \mathrm{mL}$ for MMP- 2 and $3 \mathrm{ng} / \mathrm{mL}$ for TIMP- 2 .

The total (active- and latent-form) concentrations of TGF- $\beta 1$ were assessed in aqueous humor and serum using commercially available sandwich enzyme immunoassay kits (Biosource, Camarillo, CA, USA). The sensitivity of the assays used was $15.6 \mathrm{pg} / \mathrm{mL}$.

\section{Statistical analysis}

The data collected on the cataract and PEX syndrome (with and without glaucoma) groups were statistically analyzed by Mann-Whitney $U$ test and Student's $t$-test. Paired data were analyzed by paired samples $t$-test and Wilcoxon's nonparametric test. A $P$-value of $<0.05$ was considered statistically significant.

\section{Results}

To measure quantitative differences in the concentrations of MMPs and TIMPs in aqueous humor and serum samples from individual patients with cataract and PEX syndrome (with and without glaucoma), immunoassays were performed. The results are summarized in Tables 1 and 2, in which mean results and standard deviations for each group are shown.

A considerable amount of MMP-2 was detected in aqueous humor samples from both groups of patients, but the total level of MMP-2 (proenzymes and complexed forms) was not significantly different in the PEX syndrome $(P>0.05)$ groups in comparison with control patients with cataract. Serum levels of MMP-2 in patients with PEX syndrome were slightly higher than in patients with cataract.

Table I Mean aqueous humor levels of matrix metalloproteinase-2 (MMP-2), tissue inhibitor of matrix metalloproteinase-2 (TIMP-2), and transforming growth factor beta I (TGF- $\beta \mathrm{I}$ ) in patients

\begin{tabular}{lllll}
\hline Aqueous & $\mathbf{n}$ & $\begin{array}{l}\text { TGF- } \beta \text { I } \\
(\mathbf{p g} / \mathbf{m L})\end{array}$ & $\begin{array}{l}\text { MMP-2 } \\
(\mathbf{n g} / \mathbf{m L})\end{array}$ & $\begin{array}{l}\text { TIMP-2 } \\
(\mathbf{n g} / \mathbf{m L})\end{array}$ \\
\hline Cataract control & 10 & $820.6 \pm 323.0$ & $25.3 \pm I .4$ & $35.9 \pm 15.2$ \\
PEX syndrome & 12 & $648.0 \pm 282.0$ & $25.1 \pm 1.5$ & $30.6 \pm 8.1$ \\
PEX glaucoma & 10 & $733.1 \pm 280.0$ & $25.4 \pm 2.6$ & $41.5 \pm 16.5$ \\
PEX total & 22 & $686.8 \pm 278.3$ & $25.3 \pm 2.0$ & $35.5 \pm 13.5$ \\
\hline
\end{tabular}

Note: Data are expressed as mean \pm standard deviation. Abbreviation: PEX, pseudoexfoliation. 
Table 2 Mean serum levels of matrix metalloproteinase-2 (MMP-2), tissue inhibitor of matrix metalloproteinase-2 (TIMP-2), and transforming growth factor beta I (TGF- $\beta \mathrm{I}$ ) in patients

\begin{tabular}{lllll}
\hline Serum & $\mathbf{n}$ & $\begin{array}{l}\text { TGF- } \beta \text { I } \\
(\mathbf{p g} / \mathbf{m L})\end{array}$ & $\begin{array}{l}\text { MMP-2 } \\
(\mathbf{n g} / \mathbf{m L})\end{array}$ & $\begin{array}{l}\text { TIMP-2 } \\
(\mathbf{n g} / \mathbf{m L})\end{array}$ \\
\hline Cataract control & 10 & $31,200 \pm I 2,08 I$ & $186.2 \pm 60.6$ & $38.0 \pm 14.5$ \\
PEX syndrome & 12 & $36,487 \pm 7,132$ & $204.5 \pm 59.9$ & $46.9 \pm 14.4$ \\
PEX glaucoma & 10 & $36,38 I \pm 7,597$ & $180.5 \pm 46.5$ & $51.2 \pm 18.9$ \\
PEX total & 22 & $36,439 \pm 7,169$ & $193.6 \pm 50.4$ & $48.9 \pm 16.3$ \\
\hline
\end{tabular}

Note: Data are expressed as mean \pm standard deviation. Abbreviation: PEX, pseudoexfoliation.

No significant difference in levels of TIMP-2 in the aqueous samples of patients with cataract compared with in those with PEX syndrome was demonstrated. Serum levels of TIMP-2 were elevated in patients with PEX syndrome compared with patients with cataract, but the difference did not reach statistical significance.

There was no difference in TGF- $\beta 1$ levels in the serum and aqueous samples of patients with PEX syndrome and cataract.

Aqueous and serum levels of the molecules were compared. Serum levels of MMP-2, TIMP-2, and TGF- $\beta 1$ were found to be statistically greater than their aqueous levels $(P<0.05)$, except for TIMP-2 levels in the control group.

\section{Discussion}

MMPs and their inhibitors have been previously shown in human aqueous humor and the surrounding tissues using zymographic and immunoblot techniques., ${ }^{3,16-21}$ MMPs represent a large family of endopeptidases that are capable of degrading all ECM molecules, thereby influencing cell biological activities. ${ }^{5,6}$ In addition, new proteolytic functions are increasingly being described (eg, the release of sequestered growth factors from the ECM). ${ }^{22}$ MMPs play a major role in normal matrix remodeling processes. The abnormal expression of MMPs and TIMPs or disturbances in the proteolytic balance between MMPs and TIMPs has been associated with a number of pathologic conditions including inflammatory diseases, cancer, cardiovascular disease, neurologic disease, and fibrotic conditions. ${ }^{14,22-24}$ In the eye, imbalances between MMPs and TIMPs, considered to be created by TGF- $\beta 1$, have been implicated in inflammatory and fibrotic conditions and the accumulation of abnormal fibrillar extracellular material, which is associated with PEX syndrome. . 22,22,25 $^{2}$

In the research described here, we studied aqueous and serum levels of MMP-2, TIMP-2, and TGF- $\beta 1$ in subjects with PEX syndrome, with and without glaucoma, and cataract control subjects. To our knowledge, this is the first study to have simultaneously evaluated the expression of TGF- $\beta 1$ with MMP-2 and TIMP-2 in aqueous humor and serum. We found no significant differences among the three groups in terms of mean MMP-2, TIMP-2, and TGF- $\beta 1$ levels in both aqueous humor and serum samples. In addition, we investigated the TIMP-2/MMP-2 ratio in aqueous humor and serum samples but found no statistically significant differences between the groups.

Schlötzer-Schrehardt et $\mathrm{al}^{3}$ studied aqueous samples from patients with PEX syndrome and PEX glaucoma and showed a highly significant increase in total MMP-2 and TIMP-2 compared with samples from patients with cataract. The ratio of total MMP-2 and its principal inhibitor TIMP-2 was balanced in normal cataract samples, but it was increased in PEX syndrome and primary open-angle glaucoma samples and decreased in PEX glaucoma samples. Määttä et $\mathrm{al}^{9}$ demonstrated that MMP-2 represents the major gelatinase in aqueous humor and that the aqueous TIMP-2/MMP-2 ratio is increased in PEX glaucoma. They concluded that elevation of TIMP-2 over MMP-2 supports the hypothesis that the ECM accumulation rather than degradation predominates in the pathogenesis of primary open-angle and PEX glaucoma.

Djordjević-Jocić et al ${ }^{10}$ studied MMP-2, TIMP-2, and TGF- $\beta 1$ in aqueous humor, without a serum levels' comparison, and detected the highest concentration with PEX glaucoma patients. There was a significant correlation between the aqueous levels of these molecules, and they also showed correlation with the degree of chamber angle pigmentation in the PEX glaucoma group. Their levels of MMP-2 and TIMP-2 in aqueous humor are similar to our results in PEX glaucoma, but there is more variation in values among other recent studies, which may depend on undetected factors such as ocular medication and systemic diseases (Table 3).

In our study, most of the PEX glaucoma patients had been taking prostaglandin analog eye drops for glaucoma treatment, which may trigger inflammatory processes and increased synthesis of MMP-2 in the ocular tissues. ${ }^{26}$ Konstas et al ${ }^{12}$ reported a significant reduction in aqueous TGF- $\beta 1$ after chronic latanoprost therapy in patients with PEX glaucoma. They suggested that TGF- $\beta 1$ is responsible for the synthesis of MMP-2 and TIMP-2 in PEX, and latanoprost interrupts the positive feedback cycle of TGF- $\beta 1$ accumulation. However, this mechanism needs to be supported by further studies.

In addition, some recent studies have reported that reduced levels of antioxidants and total antioxidative capacity in aqueous humor and serum cause an inaccurate antioxidative defense system in PEX syndrome patients. ${ }^{13,27}$ Since MMP-2 synthesis increases as a result of oxidative 
Table 3 Mean concentrations of matrix metalloproteinase-2 (MMP-2), tissue inhibitor of matrix metalloproteinase-2 (TIMP-2), and transforming growth factor beta I (TGF- $\beta$ I) in the aqueous humor of patients with pseudoexfoliation (PEX) glaucoma

\begin{tabular}{|c|c|c|c|c|c|c|}
\hline \multirow[t]{2}{*}{ Study } & \multicolumn{2}{|c|}{ TGF- $\beta$ I } & \multicolumn{2}{|c|}{ MMP-2 } & \multicolumn{2}{|c|}{ TIMP-2 } \\
\hline & $\mathbf{n}$ & $\mathrm{pg} / \mathrm{mL}$ & $\mathbf{n}$ & $\mathrm{ng} / \mathrm{mL}$ & $\mathbf{n}$ & $\mathrm{ng} / \mathrm{mL}$ \\
\hline \multicolumn{7}{|l|}{ Konstas et al ${ }^{12}$} \\
\hline Timolol group & 30 & $13.40 \pm 1.50$ & 30 & $81.50 \pm 7.20$ & 20 & $101.28 \pm 7.29$ \\
\hline Latanoprost group & 30 & $3.10 \pm 0.65$ & 30 & $31.75 \pm 3.80$ & 20 & $73.80 \pm 6.81$ \\
\hline Määttä et $\mathrm{al}^{9}$ & & & 16 & $77.40 \pm 33.80$ & 16 & $98.20 \pm 35.80$ \\
\hline Takai et al" & 21 & $67.70 \pm 58.70$ & & & & \\
\hline Schlötzer-Schrehardt ${ }^{13}$ & & & 30 & $107.50 \pm 60.20$ & 15 & II $4.50 \pm 48.70$ \\
\hline Djordjević-Jocić et al ${ }^{10}$ & 36 & $147.00 \pm 76.54$ & 36 & $29.00 \pm 16.80$ & 36 & $43.50 \pm 19.70$ \\
\hline Kara et al & 10 & $733.10 \pm 280.0$ & 10 & $25.40 \pm 2.60$ & 10 & $41.50 \pm 16.50$ \\
\hline
\end{tabular}

Note: Data are expressed as mean \pm standard deviation.

damage, ${ }^{28}$ samples of PEX subjects must be evaluated according to factors related to oxidative capacity.

Levels of TGF- $\beta 1$ in aqueous humor have not been well documented. ${ }^{25,29}$ It has been shown that TGF- $\beta 1$ is released from the trabecular cells as well as from the iris, ciliary body, and cornea. ${ }^{30,31}$ Koliakos et $\mathrm{al}^{25}$ showed the presence of TGF- $\beta 1$ in its latent and active form which has been ascertained and measured in the aqueous humor. They showed that both levels of total and active TGF- $\beta 1$ were significantly elevated in the aqueous humor of patients with PEX syndrome compared with age-matched controls. In contrast, no differences were observed between PEX syndrome patients and control patients in terms of serum TGF- $\beta 1$ levels. A few studies have documented elevated aqueous levels of TGF- $\beta 1$ in PEX glaucoma patients; however, a considerable variation in results makes these difficult to compare (Table 3). In spite of the fact that prostaglandin analog treatment was used by most of the PEX glaucoma patients of these studies, the range of the aqueous levels of TGF- $\beta 1$ is very high. Therefore, especially for TGF- $\beta 1$, the treatment regimen and oxidative capacity of PEX glaucoma patients must be well documented in order to find out the real effect of TGF- $\beta 1$ on metalloproteinases and their inhibitors.

\section{Limitations}

The major limitation of our study was the small number of patients. This might affect the statistical power of the study and differences in terms of MMP-2 and TIMP-2, which failed to reach a statistical significance. In addition, another limitation of this study was that we did not ascertain the active forms of the enzymes.

\section{Conclusion}

No statistically significant difference in mean MMP-2, TIMP-

2 , and TGF- $\beta 1$ levels in both aqueous humor and serum samples was found between patients with PEX syndrome and the control groups. This finding suggests that these molecules may not be major risk factors for the investigated disease, but they might be the outcomes. According to recent reports, increased oxidative stress and a genetic background may be major risk factors for PEX syndrome. In this study, despite finding no statistical difference, we demonstrated that serum levels of MMP-2, TIMP-2, and TGF- $\beta 1$ were markedly greater than the aqueous levels of them. We believe that it is important to simultaneously evaluate serum and aqueous samples of PEX syndrome while there is an impaired blood-aqueous barrier. Overall, we think that systemic pharmacological agents may be required for PEX syndrome and PEX glaucoma treatment. More research conducted with larger samples is needed to find out the right management of this systemic disorder.

\section{Disclosure}

No author has a financial or proprietary interest in any material or method mentioned in this paper.

\section{References}

1. Elhawy E, Kamthan G, Dong CQ, Danias J. Pseudoexfoliation syndrome, a systemic disorder with ocular manifestations. Hum Genomics. 2012;6:22.

2. Ritch R, Schlötzer-Schrehardt U. Exfoliation syndrome. Surv Ophthalmol. 2001;45(4):265-315.

3. Schlötzer-Schrehardt U, Lommatzsch J, Küchle M, Konstas AG, Naumann GO. Matrix metalloproteinases and their inhibitors in aqueous humor of patients with pseudoexfoliation syndrome/glaucoma and primary open-angle glaucoma. Invest Ophthalmol Vis Sci. 2003;44(3): $1117-1125$.

4. Schlötzer-Schrehardt U, Zenkel M, Küchle M, Sakai LY, Naumann GO. Role of transforming growth factor-beta1 and its latent form binding protein in pseudoexfoliation syndrome. Exp Eye Res. 2001;73(6): 765-780.

5. Woessner JF Jr. The family of matrix metalloproteinases. Ann NY Acad Sci. 1994;732:11-21.

6. Nagase H, Woessner JF Jr. Matrix metalloproteinases. J Biol Chem. 1999;274(31):21491-21494.

7. Alexander JP, Samples JR, Van Buskirk EM, Acott TS. Expression of matrix metalloproteinases and inhibitor by human trabecular meshwork. Invest Ophthalmol Vis Sci. 1991;32(1):172-180. 
8. Picht G, Welge-Luessen U, Grehn F, Lütjen-Drecoll E. Transforming growth factor beta 2 levels in the aqueous humor in different types of glaucoma and the relation to filtering bleb development. Graefes Arch Clin Exp Ophthalmol. 2001;239(3):199-207.

9. Määttä M, Tervahartiala T, Harju M, Airaksinen J, Autio-Harmainen H, Sorsa T. Matrix metalloproteinases and their tissue inhibitors in aqueous humor of patients with primary open-angle glaucoma, exfoliation syndrome, and exfoliation glaucoma. J Glaucoma. 2005;14(1): 64-69.

10. Djordjević-Jocić J, Zlatanović G, Veselinović D, et al. Transforming growth factor beta1, matrix-metalloproteinase-2 and its tissue inhibitor in patients with pseudoexfoliation glaucoma/syndrome. Vojnosanit Pregl. 2012;69(3):231-236.

11. Takai Y, Tanito M, Ohira A. Multiplex cytokine analysis of aqueous humor in eyes with primary open-angle glaucoma, exfoliation glaucoma, and cataract. Invest Ophthalmol Vis Sci. 2012;53(1):241-247.

12. Konstas AG, Koliakos GG, Karabatsas CH, et al. Latanoprost therapy reduces the levels of TGF beta 1 and gelatinases in the aqueous humour of patients with exfoliative glaucoma. Exp Eye Res. 2006;82(2): 319-322.

13. Schlötzer-Schrehardt U. [Oxidative stress and pseudoexfoliation glaucoma]. Klin Monbl Augenheilkd. 2010;227(2):108-113. German.

14. Hanemaaijer R, Sorsa T, Konttinen YT, et al. Matrix metalloproteinase- 8 is expressed in rheumatoid synovial fibroblasts and endothelial cells. Regulation by tumor necrosis factor-alpha and doxycycline. J Biol Chem. 1997;272(50):31504-31509.

15. Koliakos GG, Konstas AG, Schlötzer-Schrehardt U, Bufidis T, Georgiadis N, Ringvold A. Ascorbic acid concentration is reduced in the aqueous humor of patients with exfoliation syndrome. $\mathrm{Am} J$ Ophthalmol. 2002;134(6):879-883.

16. Gartaganis SP, Georgakopoulos CD, Mela EK, et al. Matrix metalloproteinases and their inhibitors in exfoliation syndrome. Ophthalmic Res. 2002;34(3):165-171.

17. Ando H, Twining SS, Yue BY, et al. MMPs and proteinase inhibitors in the human aqueous humor. Invest Ophthalmol Vis Sci. 1993;34(13): 3541-3548.

18. Kee C, Son S, Ahn BH. The relationship between gelatinase A activity in aqueous humor and glaucoma. J Glaucoma. 1999;8(1):51-55.

19. Vadillo-Ortega F, González-Avila G, Chevez P, Abraham CR, Montaño M, Selman-Lama M. A latent collagenase in human aqueous humor. Invest Ophthalmol Vis Sci. 1989;30(2):332-335.
20. Di Girolamo N, Verma MJ, McCluskey PJ, Lloyd A, Wakefield D. Increased matrix metalloproteinases in the aqueous humor of patients and experimental animals with uveitis. Curr Eye Res. 1996;15(10): 1060-1068.

21. Rönkkö S, Rekonen P, Kaarniranta K, Puustjärvi T, Teräsvirta M, Uusitalo H. Matrix metalloproteinases and their inhibitors in the chamber angle of normal eyes and patients with primary open-angle glaucoma and exfoliation glaucoma. Graefes Arch Clin Exp Ophthalmol. 2007;245(5):697-704.

22. Sethi CS, Bailey TA, Luthert PJ, Chong NH. Matrix metalloproteinase biology applied to vitreoretinal disorders. $\mathrm{Br} J$ Ophthalmol. 2000;84(6):654-666.

23. Schumacher S, Schlötzer-Schrehardt U, Martus P, Lang W, Naumann GO. Pseudoexfoliation syndrome and aneurysms of the abdominal aorta. Lancet. 2001;357(9253):359-360.

24. Kon CH, Occleston NL, Charteris D, Daniels J, Aylward GW, Khaw PT. A prospective study of matrix metalloproteinases in proliferative vitreoretinopathy. Invest Ophthalmol Vis Sci. 1998;39(8):1524-1529.

25. Koliakos GG, Konstas AG, Triantos A, Ritch R. Increased growth factor activity in the aqueous humour of patients with exfoliation syndrome. Graefes Arch Clin Exp Ophthalmol. 2000;238(6):491-495.

26. Gaton DD, Sagara T, Lindsey JD, et al. Increased matrix metalloproteinases 1,2 , and 3 in the monkey uveoscleral outflow pathway after topical prostaglandin $\mathrm{F} 2 \alpha$-isopropyl ester treatment. Arch Ophthalmol. 2001;119(8):1165-1170.

27. Erdurmuş M, Yağcı R, Atış Ö, Karadağ R, Akbaş A, Hepşen IF. Antioxidant status and oxidative stress in primary open angle glaucoma and pseudoexfoliative glaucoma. Curr Eye Res. 2011;36(8):713-718.

28. Galli A, Svegliati-Baroni G, Ceni E, et al. Oxidative stress stimulates proliferation and invasiveness of hepatic stellate cells via a MMP2mediated mechanism. Hepatology. 2005;41(5):1074-1084.

29. Jampel HD, Roche N, Stark WJ, Roberts AB. Transforming growth factor-beta in human aqueous humor. Curr Eye Res. 1990;9(10): 963-969.

30. Borisuth NS, Tripathi BJ, Tripathi RC. Identification and partial characterization of TGF-beta 1 receptors on trabecular cells. Invest Ophthalmol Vis Sci. 1992;33(3):596-603.

31. Knisely TL, Bleicher PA, Vibbard CA, Granstein RD. Production of latent transforming growth factor-beta and other inhibitory factors by cultured murine iris and ciliary body cells. Curr Eye Res. 1991;10(8): $761-771$.
Clinical Ophthalmology

\section{Publish your work in this journal}

Clinical Ophthalmology is an international, peer-reviewed journal covering all subspecialties within ophthalmology. Key topics include: Optometry; Visual science; Pharmacology and drug therapy in eye diseases; Basic Sciences; Primary and Secondary eye care; Patient Safety and Quality of Care Improvements. This journal is indexed on

\section{Dovepress}

PubMed Central and CAS, and is the official journal of The Society of Clinical Ophthalmology (SCO). The manuscript management system is completely online and includes a very quick and fair peer-review system, which is all easy to use. Visit http://www.dovepress.com/ testimonials.php to read real quotes from published authors. 